Review article

\title{
The taxonomy of Pseudomonas fluorescens and Pseudomonas putida: current status and need for revision
}

\author{
Emmanuel Bossis ${ }^{\mathrm{a}}$, Philippe LemanceAu ${ }^{\mathrm{b}}$, Xavier LATOUR $^{\mathrm{b} *}$, Louis GARDAN ${ }^{\mathrm{a} * *}$ \\ a INRA, Station de Pathologie Végétale et Phytobactériologie, 42 rue G. Morel, 49071 Beaucouzé Cedex, France \\ b INRA-CMSE, Laboratoire de Recherches sur la Flore Pathogène dans le Sol, 17 rue Sully, 21034 Dijon Cedex, France
}

(Received 8 April 1999; accepted 22 November 1999)

\begin{abstract}
Summary - Many studies are devoted to the ecology of Pseudomonas fluorescens and Pseudomonas putida. Indeed, bacteria belonging to these species could potentially be used for environmental purposes. Some strains are able to improve plant growth and plant health, and consequently could contribute to reduce the use of chemical inputs in agriculture. Others are able to dissimilate nitrates and to degrade xenobiotic compounds. Accurate identification of the bacterial strains tested in these ecological studies is needed. The purpose of this review is to describe the status of the taxonomy of $P$. fluorescens and $P$. putida and to present the methods available for speciation. The first works on the taxonomy of $P$. fluorescens and $P$. putida were based on phenotypic characters such as metabolic tests, fatty acid composition and protein profiles. These studies led to the subdivision of $P$. fluorescens and $P$. putida into 5 and 2 biovars, respectively. From these phenotypic characters, two dichotomous keys were proposed to differentiate quickly strains belonging to $P$. fluorescens and $P$. putida. The subdivision of these species into biovars indicates that identification based on phenotypic characters is not fully satisfactory. Further work has focused on genotypic characters based on the variability of consensus genes (rDNA) or of the total genome (DNA-DNA hybridization). Collectively, results from taxonomic studies of $P$. fluorescens and $P$. putida show that the present delineation of these two species is obsolete and that they should be divided in many nomenspecies. Further research, combining both recent phenotypic and genotypic methods, is required to clarify the taxonomy of $P$. fluorescens and $P$. putida.
\end{abstract}

taxonomy / Pseudomonas fluorescens / P. putida / phenotypic characterization / genotypic characterization

Communicated by Edward Topp (London, Canada)

* present address : Laboratoire de Microbiologie du Froid, 55 rue St-Germain, 27000 Evreux, France

** Correspondence and reprints

gardan@angers.inra.fr 
Résumé - Situation actuelle et limites de la taxonomie des Pseudomonas fluorescens et Pseudomonas putida. De nombreuses études sont dédiées à l'écologie des Pseudomonas fluorescens et des Pseudomonas putida. Les bactéries appartenant à ces espèces présentent en effet un intérêt potentiel pour l'environnement. Certaines améliorent la croissance et la santé des plantes, et contribuent donc à réduire l'utilisation d'intrants de synthèse en agriculture. D'autres sont capables de réduire les oxydes d'azote et de dégrader les composés xénobiotiques. L'identification précise des souches bactériennes utilisées lors de ces études d'écologie est nécessaire. L'objectif de cette synthèse bibliographique est de décrire l'état de la taxonomie de $P$. fluorescens et $P$. putida et de présenter les méthodes permettant la discrimination de ces deux espèces. Les premiers travaux relatifs à la taxonomie de $P$. fluorescens et de $P$. putida étaient basés sur la caractérisation phénotypique des bactéries (tests métaboliques, composition des acides gras, profils protéiques). Ces études ont abouti à la subdivision de $P$. fluorescens et $P$. putida en respectivement 5 et 2 biovars. La subdivision de ces deux espèces en biovars révèle les limites de l'identification basée sur des caractères phénotypiques. Des travaux complémentaires ont donc pris en compte certains caractères génotypiques tels que la variabilité de gènes conservés (ADNr) et l'ensemble du génome (hydridation ADN-ADN). L'ensemble des travaux conduits sur la taxonomie de $P$. fluorescens et de $P$. putida montre que la définition de ces deux espèces est obsolète et qu'elles devraient être divisées en plusieurs nomenspecies. La clarification de la taxonomie de $P$. fluorescens et de $P$. putida requiert des recherches complémentaires qui associent des méthodes phénotypiques récentes, et génotypiques.

taxonomie / Pseudomonas fluorescens / P. putida / caractérisation phénotypique / caractérisation génotypique

\section{Introduction}

The genus Pseudomonas sensu stricto belongs to the $\gamma$ subclass of the Proteobacteria (Fig. 1) and contains mostly fluorescent Pseudomonas spp. as well as a few non-fluorescent species. This genus contains (i) phytopathogenic cytochrome c oxidase-positive fluorescent Pseudomonas such as $P$. cichorii, P. marginalis and $P$. tolaasii [57] and nonphytopathogenic, non-necrogenic strains such as $P$. fluorescens, $P$. putida, P. chlororaphis, $P$. aureofaciens and the $P$. aeruginosa type species; (ii) necrogenic phytopathogenic fluorescent Pseudomonas spp. without cytochrome c oxidase: $P$. syringae and $P$. viridiflava; (iii) non-fluorescent Pseudomonas spp.: P. stutzeri, $P$. mendocina, $P$. alcaligenes and $P$. pseudoalcaligenes. The complete revised list of species included in this genus is given by Kersters et al. [23].

$P$. fluorescens and $P$. putida are ubiquitous bacteria. They frequently are present in water, in soils, and especially in the plant rhizosphere. Many studies are devoted to these bacteria. Indeed, some of them improve plant growth and plant health and are implicated in the natural suppressiveness of certain soils to various soilborne diseases [29, 54] whereas others are involved in the biodegradation of natural or man-made toxic chemical compounds [14]. Besides these soil-borne strains, P. fluorescens and $P$. putida also belong to the epiphyllous community of numerous plant species [16, 41]. Some of them are responsible for damage in leaf vegetables and are opportunistic macerating plant pathogens [15]. P. fluorescens and P. putida from meat and milk are responsible for degrading curing conditions $[31,33]$.

The importance of $P$. fluorescens and $P$. putida in various environments has initiated numerous ecological studies on these bacteria $[8,10,20-22$, 27, 30, 40, 41, 52]. During such studies, investigators are often faced with difficulties in identifying the strains studied. The aim of the present review is to describe the state of the art on the taxonomy of these two species. Up to now, characterisation has been performed by using chemotaxonomic and genomic methods. These methods will be reviewed and their limitations will be discussed.

\section{Phenotypic characterization}

Over decades, bacteria have been characterised, clustered and identified according to a few phenotypic characters such as morphology, pigmentation, 


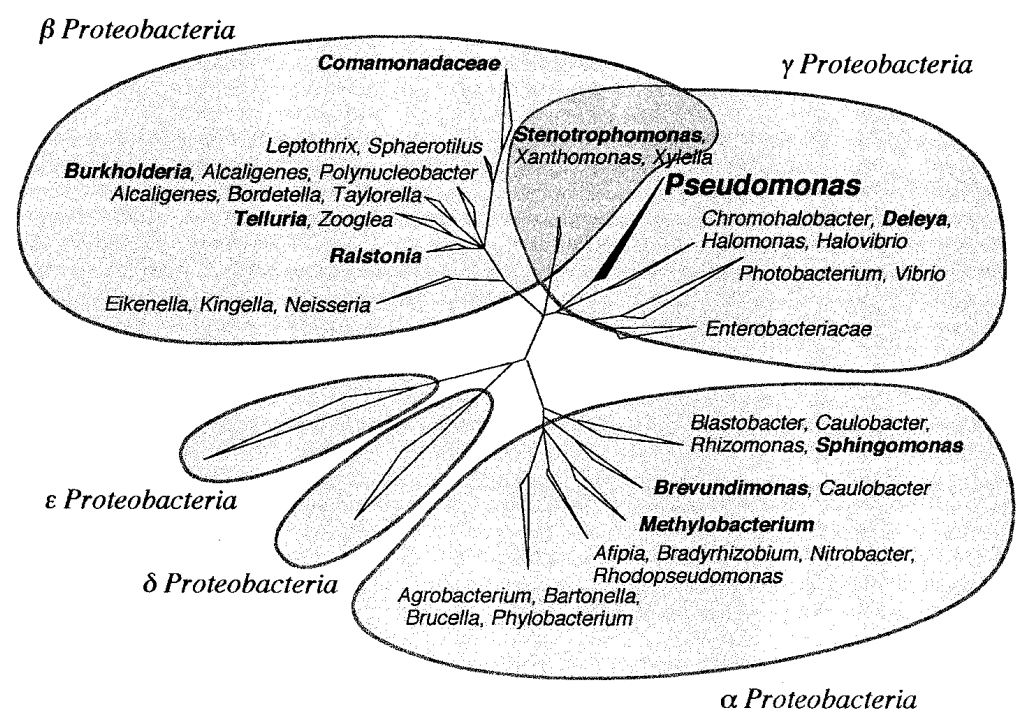

Fig 1. Phylogenic relationships of proteobacterial group containing species currently or formerly assigned to the genus Pseudomonas (bold) and selected groups (adapted from Kersters et al., 1996).

reaction to dyes, the presence or absence of spores, nutritional requirements, ability to produce acids from sugars, and sensitivity to inhibitors. These simplified characterisation methods are still the basis of classification and identification systems. The study of Jessen [18], who classified a large collection of fluorescent Pseudomonas into 82 biotypes, and those of Lelliott et al. [28] and Stanier et al. [48], improved the classification of this group and its subdivision into species and biotypes.

In a large phenotypic study on 267 non-phytopathogenic Pseudomonas strains of various origins, among which 175 were fluorescent, Stanier et al. [48] examined 146 nutritional properties. They showed that $P$. fluorescens and $P$. putida species are very heterogeneous. The $P$. fluorescens species was subdivided into 7 biotypes. The biotypes $\mathrm{A}, \mathrm{B}, \mathrm{C}, \mathrm{D}$ and $\mathrm{F}$ were then called biovars (bv. I to $\mathrm{V}$ ) and the biotypes $\mathrm{D}$ and $\mathrm{E}$ became the $P$. chlororaphis and P. aureofaciens species, respec- tively [35] which were then clustered as the $P$. chlororaphis species [19]. P. putida also was subdivided into biotypes $\mathrm{A}$ and $\mathrm{B}$, which became biovars A and B. P. fluorescens bv. V is an heterogeneous subset including strains which often cannot be classified because they have lost properties considered as essential for the differentiation from other biovars [35]. The heterogeneity of biovar $\mathrm{V}$ made it impossible to designate reference strains for this biovar. This system of multiple biovars reveals a high phenotypic heterogeneity, which probably reflects a high genomic heterogeneity. It is the only system available and is thus widely used.

Jacques [15] and Bossis [2] proposed dichotomous keys for the preliminary identification of oxidase-positive fluorescent Pseudomonas spp. based on the most discriminating characters according to Stanier et al. [48] and Palleroni [35] (Fig. 2). These keys allow easier identification of species and 

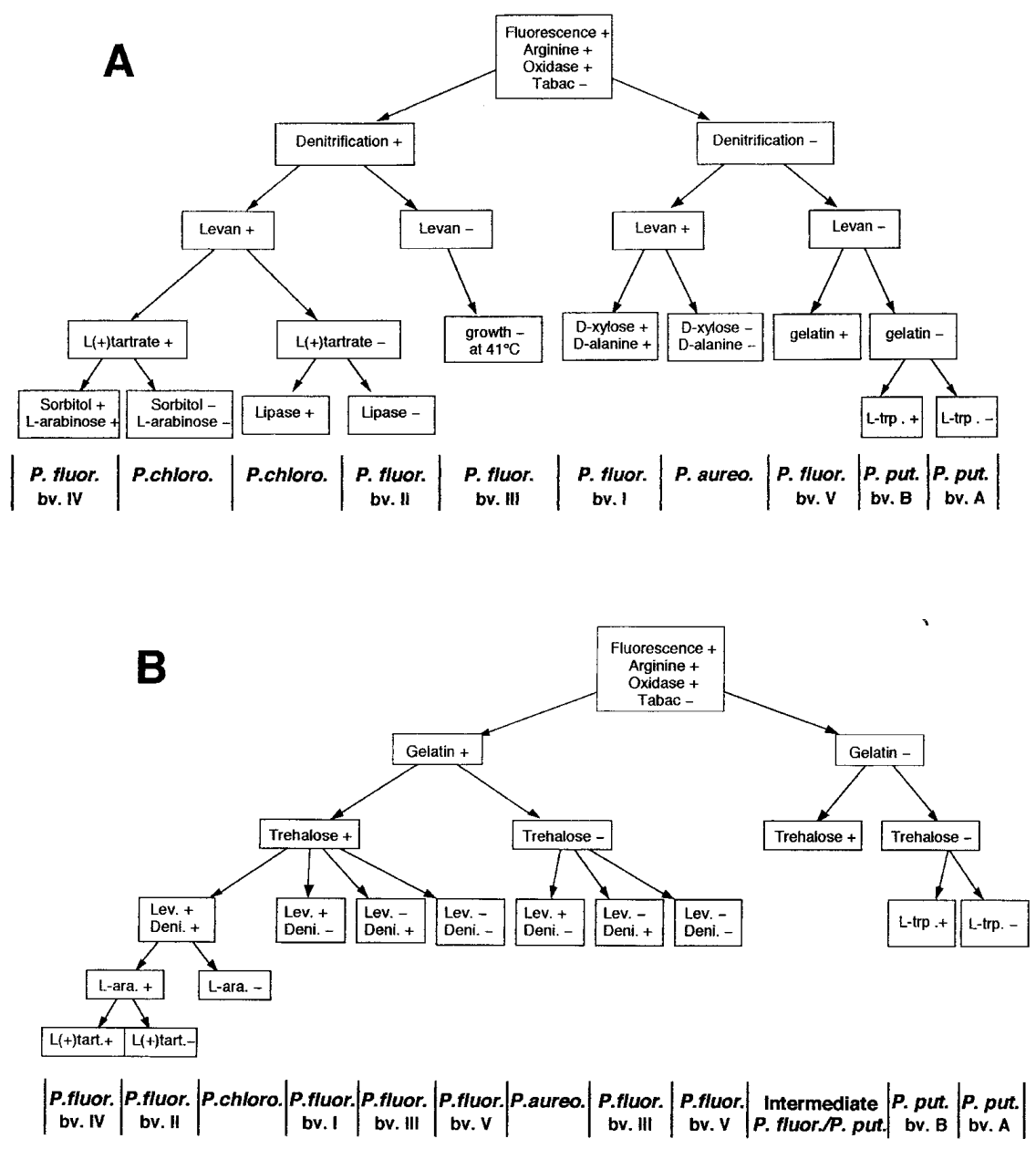

Fig 2. Dichotomous keys proposed by (A) Jacques (1994) and by (B) Bossis (1995) for the identification of strains belonging to $P$. fluorescens and P. putida species. Abbreviations: P. aureo.: Pseudomonas aureofaciens; P. chloro.: P. chlororaphis; P. fluo.: P. fluorescens; P. put.: P. putida; L-ara: L-arabinose; Den.: Denitrification; Lev.: Levan; L (+) tart.: L(+) tartrate; L-trp.: L-tryptophan.

biovars $[6,26,30]$. However, this type of method presents two major limitations: (i) it attributes too much importance to some properties; and (ii) the number of properties taken into account is small. Indeed, the strains identified with the dichotomous key proposed by Bossis [2] differed by several characters from the corresponding reference strains defined by Palleroni [35] on the basis of 105 char- acters (Tab. I). Furthermore, since the differentiation of the strains into biovars is based on several properties, the application of the dichotomous keys cannot always assign a strain to a specific biovar (around 10\%). Finally, identifications performed by these two keys are sometimes different (about $25 \%)$. In spite of these limitations, the dichoto- 
Table I. Number of characters by which strains identified with the dichotomous key of Bossis (1995) as $P$. fluorescens or $P$. putida differ from the corresponding reference strains identified using the 105 characters defined by Palleroni (1984) (reproduced from Bossis, 1995).

\begin{tabular}{lllllllll}
\hline & & \multicolumn{3}{c}{ P. fluorescens } & & \multicolumn{2}{c}{ P. putida } \\
& & bv. I & bv. II & bv. III bv. IV & bv. V & bv. A & bv. B \\
\hline P. fluorescens & bv. I & - & 4 & 3 & 7 & 2 & 11 & 15 \\
& bv. II & & - & 2 & 3 & 3 & 9 & 13 \\
& bv. III & & - & 4 & 2 & 5 & 7 \\
& bv. IV & & & - & 4 & 12 & 19 \\
P. putida & bv. V & & & & - & 2 & 4 \\
& bv. A & & & & & - & 3 \\
& bv. B & & & & & & - \\
\hline
\end{tabular}

mous keys are still applied because no other method so far is more satisfactory.

In contrast to dichotomic keys, numerical taxonomy according to Adamson's principles takes into account a large number of phenotypic properties, all of which are given the same importance and analysed mathematically in order to classify strains objectively [44]. A minimum of 50 characters such as morphological, physiological, biochemical, nutritional and serological criteria, chosen carefully, are required for such analysis. The similarities between strains are calculated by using a numerical index that reveals pairwise strain similarities. Strains showing a high level of similarity are clustered in a phenon. At each delineation level, it is possible to define characteristics which discriminate phenons and enable the identification of strains [7]. According to Sneath [43], the clusters of strains showing about $80 \%$ similarity generally correspond to bacterial species, while the groups at $60 \%$ similarity would correspond to genera. However, in our experience this rule usually cannot be applied [11].

The data published by Stanier et al. [48] have been analysed by numerical taxonomy [45]. This numerical analysis showed that the groups formed by the $P$. fluorescens and $P$. putida species are different but close and that the $P$. fluorescens biovars do not exactly match the delineated phenotypic clusters: some strains belonging to different biovars are classified into the same cluster and other strains from the same biovar are classified into different phenons. Champion et al. [4] carried out a numerical analysis with 93 P. fluorescens strains belonging to all the biovars except for biovar V. They defined subgroups of each biovar. Biovar I was divided into subgroup $\mathrm{I}-1$, which is close to $P$. chlororaphis and $P$. aureofaciens, and subgroup I-2. Biovar II was composed of three subgroups and biovars III and IV were each composed of two subgroups. Similarly, a numerical analysis was performed by Barrett et al. [1] on 72 strains of P. fluorescens bv. V. This biovar was subdivided in 7 subgroups (from V-1 to V-7) showing a level of similarity at least equal to $77 \%$. Subgroup V-1 contained 38 strains which were very close to those from biovar I-2 described by Champion et al. [4]. This subgroup was called biovar VI of $P$. fluorescens. Subgroup V-6, including 16 strains, constituted the true biovar V which was close to biovars I and II of Stanier. Subgroups V-5 and V-7, which were close to $P$. putida, now constitute a new biovar (bv. C) of $P$. putida. In 1990, Stenström et al. [50] showed that some P. putida strains cannot be affiliated with any of the biovars described. Elomari et al. [9] distinguished four distant subgroups of $P$. putida biovar A and suggested that $P$. putida must be divided into several species. All these examples clearly illustrate the need for a numerical taxonomy approach when applying phenotypic tests.

Together, these results indicate that the current definition of the biovars is not precise enough. Discrepancies between the taxonomic identification based on dichotomic keys and the numerical analysis of phenotypic data have been reported by Bossis [2], Lemanceau et al. [30] and Latour et al. [26]. These authors have compared the phenotypic clusters resulting from the numerical analysis and the taxonomical identification of strains isolated from bulk and rhizospheric soils. Strains belonging to a same biovar were distributed into different phenotypic clusters. 
Taking into consideration the limits of identification based on the dichotomous keys and the need to include a large number of bacterial traits to identify strains accurately, it has been proposed that commercial kits such as: API-50CH, -50A0 and 50AA and currently Biotype 100 (bioMérieux, La Balme les Grottes, France) and Biolog MicroPlate system (Biolog Inc., Hayward, USA) be used for taxonomic analysis. These kits allow determination of the ability of isolates to assimilate (bioMérieux system) or to oxidize in the presence of tetrazolium salt (Biolog system) a wide range of organic compounds. Usually, additional biochemical tests also are used in order to increase the accuracy of the results. The iterative comparison of the patterns obtained with those of reference strains available in a data bank allows taxonomical determination of isolates from nature with a given level of confidence. Studying a collection of 224 strains of the genus Pseudomonas, Grimont et al. [12] established that the clustering patterns and strain identification based on analyses with Biotype 100 or by Biolog GN microplates were similar. However, using these commercial tests we recorded discrepancies in the identification of 19 type strains and 60 reference strains of $P$. fluorescens and $P$. putida [2]. Further studies are needed to increase the amount of information available in the data bank on oxidase-positive fluorescent pseudomonads in order to improve the reliability of these commercial tests.

Besides the enzymatic and metabolic activities, fatty acid composition and protein profiles have been proposed as methods for taxonomic identification of $P$. fluorescens and $P$. putida. Fatty acids are methylated, esterified and then analysed by gas chromatography. This method enabled Stead [49] to identify a group corresponding to the rRNA homology group of $P$. fluorescens among 340 strains of plant pathogenic bacteria and a few saprophytic bacteria. In this study, fluorescent Pseudomonas were clustered in subgroup 1-a, which was the only one to contain several taxons. Differences in the fatty acid profiles were observed between these taxons even at an intraspecific level. As an example, the profile of $P$. fluorescens biovar IV differed from that of other biovars, whereas profiles of $P$. fluorescens bv. I, II and V were very similar. Janse et al. [17] analysed the fatty acid profiles of pathogenic and saprophytic fluorescent Pseudomonas and distinguished four groups. The supergroup D contained all the $P$. fluorescens and $P$. putida biovars. Differentiation of the different $P$. fluorescens and $P$. putida biovars was not possible. According to these authors, oxidase-positive fluorescent Pseudomonas comprise a large continuum of bacteria and fatty acid profiles do not seem well adapted for identification of the strains.

SDS-PAGE analysis of whole-cell lysates followed by proteinase $\mathrm{K}$ digestion and analysis of only four characteristic protein-fragment bands enabled Sorensen et al. (1991) [46] to rapidly identify $P$. aeruginosa, $P$. fluorescens and $P$. putida at a specific level. However, the identification at the biovar level could not be achieved in a reliable way [51].

Collectively, studies on the phenotypic characterization of $P$. fluorescens and $P$. putida indicate high variability within these two species, which has resulted in subdivision into biovars and intrabiovar subgroups. Genotypic characterization of these species and biovars is required to clarify the real taxonomic status of these subdivisions.

\section{Genotypic characterization}

DNA-rRNA hybridization studies led to the delineation of the genus Pseudomonas into five homology groups [39]. The genus Pseudomonas sensu stricto corresponds to the Palleroni sensu rRNA homology group I and contains all the fluorescent species [35].

In 1987, species were defined phylogenetically by Wayne et al. [53] as clusters of bacterial strains showing a level of similarity of their DNA greater than $70 \%$ by DNA-DNA hybridization and showing a difference in the denaturation temperature of their DNA of less than $5{ }^{\circ} \mathrm{C}$. Genomic studies involving DNA-DNA hybridization in the Palleroni sensu rRNA homology group I are rare. Palleroni et al. [38, 39] studied the relationships between $P$. fluorescens and $P$. putida species as 
Table II. Percentage of reassociation among P. fluorescens and P. putida biovars (adapted from Palleroni et al., 1972).

\begin{tabular}{|c|c|c|c|c|c|c|}
\hline & \multirow{3}{*}{ Labelled DNA from } & \multicolumn{5}{|c|}{ Unlabelled DNA from } \\
\hline & & \multicolumn{3}{|c|}{ P. fluorescens } & \multicolumn{2}{|c|}{ P. putida } \\
\hline & & bv. I & bv. II & bv. III & bv. A & bv. B \\
\hline \multirow[t]{2}{*}{ P. fluorescens } & number of strains tested & 14 & 11 & 13 & 5 & 3 \\
\hline & $\%$ of reassociation & 52 to 73 & 21 to 81 & 26 to 78 & 21 to 45 & 24 to 58 \\
\hline \multirow[t]{2}{*}{ P. putida } & number of strains tested & 7 & 4 & 4 & 15 & 5 \\
\hline & $\%$ of reassociation & 32 to 50 & 24 to 44 & 23 to 45 & 18 to 78 & 42 to 76 \\
\hline
\end{tabular}

well as between their biovars by using the competition DNA-DNA hybridization technique with a limited number of strains. They showed the presence of a large genomic variability between biovars as well as between strains of a given biovar [38]. The values of hybridization percentages between strains within biovars as well as between biovars usually were lower than $70 \%$ (Tab. II). Using a larger number of strains, Champion et al. [4] came to the same conclusions as Palleroni and coworkers [38, 39] regarding the high diversity within the $P$. fluorescens and $P$. putida species. Taken together, these different studies show that the genomic variability within biovars of $P$. fluorescens and $P$. putida is very high and that biovars probably correspond to species. According to Palleroni [36], P. fluorescens and P. putida could comprise up to 500 species. This suggestion is strengthened by our recent work showing that the level of DNA similarity of rhizosphere isolates identified as $P$. fluorescens or $P$. putida by the phenotypic criteria of Palleroni [35] was never greater than $55 \%$ as compared with the type strains of $P$. fluorescens and $P$. putida [2].

Although DNA-DNA hybridization procedures allow accurate identification of the genomic species, they are expensive and time-consuming to use. Other molecular techniques, such as comparing portions of conserved sequences, hybridization with DNA probes, and analysis of sequence polymorphism after PCR amplification or not, seem more appropriate for rapid identification of a large number of strains.

Genes coding for $16 \mathrm{~S}$ and $23 \mathrm{~S}$ rRNA are known to be subjected to a high selective pressure, which could explain why they are highly conserved and their use in taxonomic studies is common [56]. According to Stackebrandt and Goebel [47] two strains definitely belong to different species if they share less than $97 \%$ homology of $16 \mathrm{~S}$ rRNA sequences. When the homology percentage is greater than $97 \%$, total DNA-DNA hybridizations must be carried out to establish whether they belong to the same species.

After having sequenced most of the $16 \mathrm{~S}$ rRNA genes of strains belonging to 21 different species within the genus Pseudomonas, Moore et al. [34] delineated a so-called Pseudomonas fluorescens lineage including the species $P$. fluorescens together with $P$. aureofaciens, $P$. chlororaphis, $P$. marginalis, $P$. tolaasi and $P$. viridiflava. A high level of similarity of the 16S rRNA genes (between $98.3 \%$ and $99.5 \%$ ) of these species was recorded. The comparison of an hypervariable region of these genes indicated heterogeneity of a similar magnitude within the different biovars of $P$. fluorescens as within the various species belonging to the $P$. fluorescens lineage. In the same way, a high degree of heterogeneity between the sequences of the $16 \mathrm{~S}$ rRNA genes (3\%) of strains belonging to biovars A and $\mathrm{B}$ of $P$. putida was described by these authors. 
Such results suggest that strains belonging to biovars A and B actually belong to different species sensu Stackebrandt and Goebel. Christensen et al. [5] stressed the lack of relation between phenotypic characterization (intracellular protein patterns and biochemical tests) and characterization based on the sequences analysis of two regions of $23 \mathrm{~S}$ rDNA. Furthermore, sequence analysis of these regions did not allow clear distinctions at the species level among strains of $P$. fluorescens and $P$. putida and at the biovar level within $P$. fluorescens. In contrast, Widmer et al. [55] recently developed a PCR protocol for selective detection of Pseudomonas in environmental samples. This protocol is based on the amplification of Pseudomonas 16S rRNA genes with highly selective primers and restriction analysis of the PCR product with HaeIII. Phylogenetic analysis allows the clear discrimination of $P$. fluorescens and $P$. putida species.

The variability of ribosomal DNA within species also can be assessed by using nucleic acid probes. Schleifer et al. [42] defined two probes (Ps and $\mathrm{Ppu}$ ) on the basis of a short sequence (15 bp) of $23 \mathrm{~S}$ rDNA. Ps allows the detection of strains belonging to fluorescent pseudomonads except $P$. putida. The Ppu probe, differing from Ps by a single base pair, allows only the detection of $P$. putida.

Laguerre et al. [24] have evaluated the possible application of the polymorphism of the $16 \mathrm{~S}$ rRNA gene in the taxonomy of fluorescent pseudomonads. This polymorphism was evaluated by the Restriction Fragment Length Polymorphism (RFLP) analysis of 16S rDNA amplified by PCR by using universal primers. RFLP Patterns of the 16S rDNA amplified by PCR and digested by 13 restriction endonucleases of 31 strains belonging to 10 different species were compared. The combined data from restriction analysis defined 17 different $16 \mathrm{~S}$ rDNA genotypes. The groupings obtained were well-correlated with the DNA-DNA hybridization data available (Palleroni [38, 39]; Johnson and Palleroni [19]); confirmed the heterogeneity of strains belonging to $P$. putida species; and, to a lesser extent, the heterogeneity of strains belonging to $P$. fluorescens species. The seven strains belonging to $P$. fluorescens bv. I, II, III and $\mathrm{V}$ formed a tight cluster (mean divergence of $1.6 \%$ base substitution among the four genotypes recorded). Two $P$. fluorescens bv. IV strains and the $P$. fluorescens bv. VI strain showing the same genotype as the $P$. putida bv. B strain were regrouped in the $P$. fluorescens cluster. The five strains of $P$. putida tested did not cluster and the sequence divergence between the four genotypes identified within this species ranged from 3.2 to $13.6 \%$ base substitutions.

Brosch et al. [3] used another form of ribotyping to assess the taxonomic diversity of a collection of 226 strains of Pseudomonas. The main steps of this method are as follows: automated DNA extraction and purification, hybridization with $16+23 \mathrm{~S}$ rRNA probe, digestion with SmaI and HincII endonucleases, computer capture of restriction patterns with automatic migration measurements, fragment size interpolation, and comparison of patterns using programs of the Taxotron package (Institut Pasteur, Paris, France). Clustering of the strains by ribotyping and by phenotypic characterization (Biotype 100 strips or Biolog GN microplates) was well related. Most $(92.7 \%)$ of the ribogroups obtained were homogeneous with respect to species (nomenspecies used), some nomenspecies like $P$. fluorescens and $P$. putida being split in several ribogroups. Indeed, within these two species, biovars formed distinct ribogroups. Genomic species delineation was evaluated by DNA-DNA hybridization. The ribogroup which includes most of $P$. fluorescens bv. I strains was found to constitute a DNA hybridization group distinct from $P$. fluorescens strains belonging to other ribogroups or biovars. The ribogroup including most $P$. putida bv. A strains constituted a DNA relatedness group distinct from $P$. putida bv. B strains. These authors then proposed to give other species names to strains of $P$. putida bv. B and to some $P$. putida bv. A isolates showing atypical ribotypes. Using another endonuclease ( $P v u \mathrm{II})$, Elomari et al. [9] observed a good correlation between ribotyping analyses and studies on numerical taxonomy for strains isolated from clinical samples belonging to $P$. putida bv. A and confirmed the great heterogeneity within this species. 


\section{Conclusion}

Numerous studies have emphasized the high level of diversity within $P$. fluorescens and $P$. puti$d a$. This high degree of diversity has led to the subdivision of these two species in biovars and to the definition of two new species, $P$. aureofaciens and $P$. chlororaphis, which were later shown to be synonymous [19]. The diversity described within $P$. fluorescens and within $P$. putida could be associated with the variety of their habitats (soil, water, plants, meat and dairy products, and animal and human clinical specimens). Environmental and trophic factors may play a major role in the evolution of bacteria. Some of these factors probably are implicated in the speciation of these ubiquitous bacteria. Indeed, the carbon and energy metabolism of $P$. fluorescens and $P$. putida varies depending on the environment from which they have been isolated [25]. The diversity among bacteria belonging to $P$. fluorescens and $P$. putida according to their environment was expressed not only at the phenotypic level but also at the genotypic level. This genotypic diversity was even recorded in consensus genes (rDNA).

Considering the high level of genomic diversity within P. fluorescens and P. putida, their taxonomy should be revised. The application of the now recognized rules defined by Wayne et al. [53] shows that $P$. fluorescens and $P$. putida are distinct species and that many new species should be delineated within the different biovars. Palleroni [36] estimated that these two species in fact include several hundred species. Janse et al. [17] and Doudoroff, quoted by Palleroni [37], assumed a continuum in $P$. fluorescens and $P$. putida species and even in other species, such as $P$. syringae and its pathovars [13]. This assumption was recently strengthened by our data showing that the genomic relationships with strains identified as $P$. fluorescens and $P$. puti$d a$ on the basis of phenotypic traits varied from 0 to $100 \%[2,26,30]$. Several recent studies agree on the need to reclassify the strains previously identified as $P$. fluorescens and $P$. putida.

Clarifying the taxonomy of this group will only be possible by using collections of strains from dif- ferent origins and representative of all the biovars. These collections seem to exist and could be exchanged between different laboratories. The DNA-DNA hybridization technique makes it possible to assess the genomic relationship between strains as compared to the species from a sample of strains representative of well-defined phenotypic groups. As the species are defined by DNA-DNA hybridization [53], the method consists of (i) defining genomic hybridization groups corresponding to species and (ii) checking whether these genomic groups are consistent with phenotypic groupings used for strain identification. Studies should implement all the phenotypic and genomic techniques including metabolic tests, protein profiles, sequencing of rDNA and its intergenic regions, the use of probes with different specificity, quantitative DNA-DNA hybridizations, and analysis of restriction fragments obtained by different methods (Fig. 3). The double approach, based on genotypic and phenotypic characterization, has recently been illustrated by Grimont et al. [12] and Brosch et al. [3], who demonstrated a good relationship between clustering made by ribotyping to the one made by DNA-DNA hybridization and to the one made by phenotypic tests. This approach also is currently applied to stress the good correspondence between the siderotypes of the fluorescent pseudomonads [32], their auxanograms, their $16 \mathrm{~S}$ rDNA RFLP-patterns and their DNA-DNA similarities (Meyer J.M., Coulange V., Izard D., Lemanceau P. and Gardan L., unpublished data).

The numerous ongoing studies on the ecology of fluorescent pseudomonads require reliable, fast and cheap methods to identify large numbers of isolates. The methods described above are well adapted to fulfill this requirement: (i) these methods can be applied to cluster the isolates, and (ii) the level of similarity of the DNA of reference strains representative of each cluster can be determinated relative to DNA of type strains of species and biovars previously delineated. The delineation of new species within the distinct species $P$. fluorescens and $P$. putida remains to be done in order to clarify their taxonomy. 


\section{POLYPHASIC TAXONOMY OF \\ P. FLUORESCENS AND P. PUTIDA}

1. ISOLATION IN PURE CULTURE

2. PHENOTYPIC STUDY
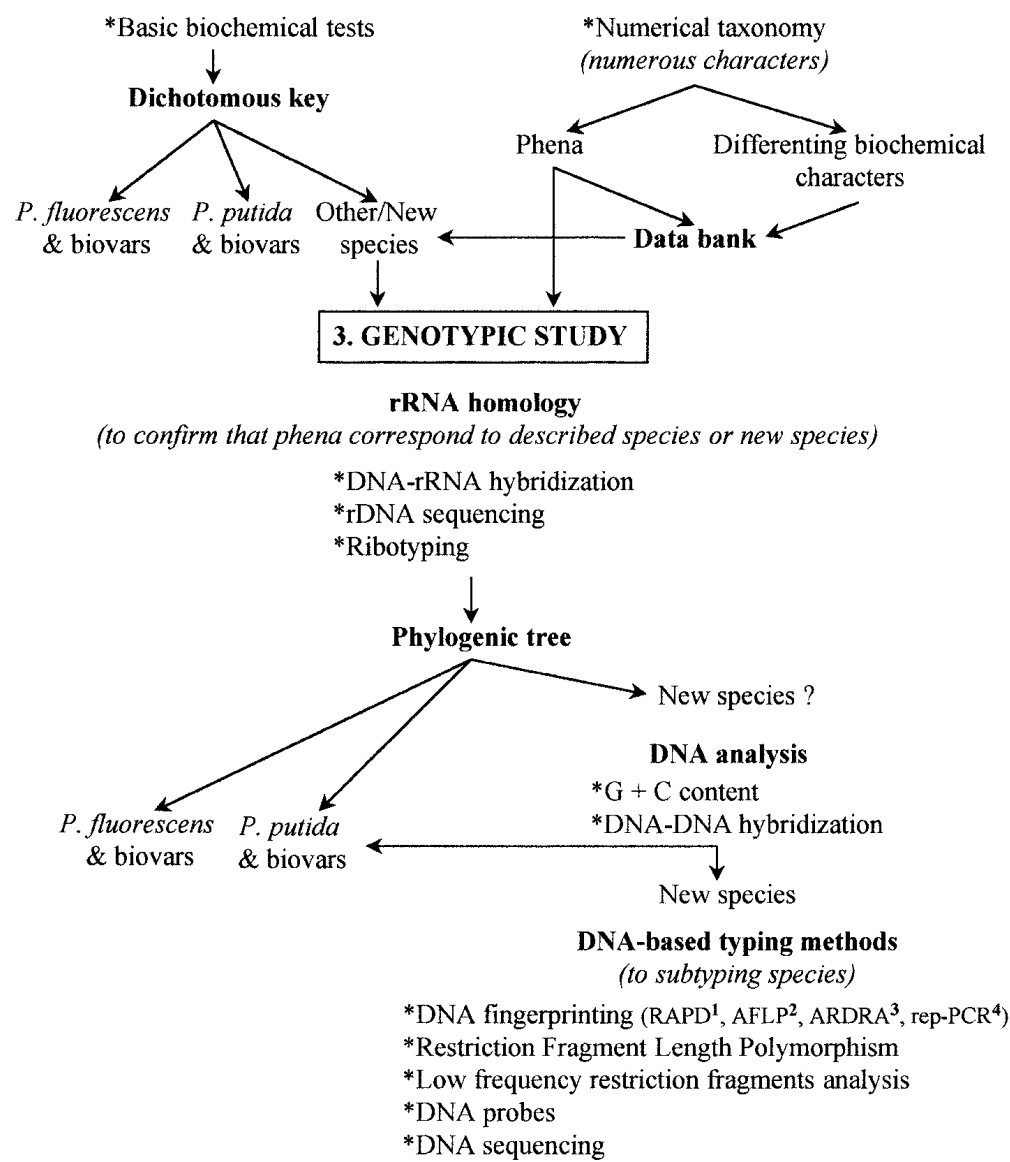

Fig 3. Proposed flow chart to study polyphasic taxonomy of P. fluorescens and P. putida. Abbreviations: ${ }^{1}$ Random Amplified Polymorphic DNA; ${ }^{2}$ Amplified Fragment Length Polymorphism; ${ }^{3}$ Amplified rDNA Restriction Analysis $;{ }^{4}$ Amplification of repetitive sequences.

\section{References}

[1] Barrett E.J., Solanes R.E., Tang J.S., Palleroni N.J., Pseudomonas fluorescens biovar V: its resolution into distinct groups and relationships of these groups to other P. fluorescens biovars, to P. putida, and to psychrotrophic pseudomonads associated with food spoliage, J. Gen. Microbiol. 132 (1986) 2709-2721.

[2] Bossis E., Les Pseudomonas fluorescents de la rhizosphère : étude taxonomique et effets sur la crois- 
sance de la tomate et du maïs, de la germination à la levée, Thèse de doctorat, Université de Nantes, France, 1995, 143p.

[3] Brosch R., Lefèvre M., Grimont F., Grimont P.A.D., Taxonomic diversity of pseudomonads revealed by computer-interpretation of ribotyping data, Syst. Appl. Microbiol. 19 (1996) 541-555.

[4] Champion A.B., Barrett E.L., Palleroni N.J., Evolution in Pseudomonas fluorescens, J. Gen. Microbiol. 120 (1980) 485-511.

[5] Christensen H., Boye M., Poulsen L.K., Rasmussen O.F., Analysis of fluorescent pseudomonads based on $23 \mathrm{~S}$ ribosomal DNA sequences, Appl. Environ. Microbiol. 60 (1994) 2196-2199.

[6] Clays-Josserand A., Lemanceau P., Philippot L., Lensi R., Influence of two plant species (flax and tomato) on the distribution of nitrogen dissimilative abilities within fluorescent Pseudomonas spp., Appl. Environ. Microbiol. 61 (1995) 1745-1749.

[7] Descamp P., Véron M., Une méthode de choix des caractères d'identification basée sur le théorème de Bayes et la mesure de l'information, Ann. Microb. 132B (1981) 157-170.

[8] Digat B., Gardan L., Caractérisation, variabilité et sélection des souches bénéfiques de Pseudomonas fluorescens et $P$. putida, EPPO Bull. 17 (1987) 559-568.

[9] Elomari M., Izard D., Vincent D., Coroler L., Leclerc H., Comparison of ribotyping analysis and numerical taxonomy studies of Pseudomonas putida biovar A, Syst. Appl. Microbiol. 17 (1994) 361-369.

[10] Frey P., Frey-Klett P., Garbaye J., Berge O., Heulin T., Metabolic and genotypic fingerprinting of fluorescent pseudomonads associated with the Douglas Fir-Laccaria bicolor mycorrhizosphere, Appl. Environ. Microbiol. 63 (1997) 1852-1860.

[11] Gardan L., Bollet C., Abu Ghorrah M., Grimont F., Grimont P.A.D., DNA relatedness among pathovar strains of Pseudomonas syringae pv. savastanoi Janse (1982) and proposal of Pseudomonas savastanoi sp. nov., Int. J. Syst. Bacteriol. 42 (1992) 606-612.

[12] Grimont P.A.D., Vancanneyt M., Lefèvre M., Vandemeulebroecke K., Vauterin L., Brosch R., Kersters K., Grimont F., Ability of Biolog and Biotype100 systems to reveal the taxonomic diversity of the pseudomonads, Syst. Appl. Microbiol. 19 (1996) 510-527.

[13] Hildebrand D.C., Huisman O.C., Schroth M.N., Use of DNA hybridization values to construct threedimentional models of fluorescent pseudomonad relationships, Canad. J. Microbiol. 30 (1983) 306-315.
[14] Holloway B., Pseudomonas in the late twentieth century, in: Galli E., Silver S., Witholt B. (Eds.), Pseudomonas molecular biology and biotechnology, Am. Soc. Microbiol., Washington, DC, 1992, pp. 1-8.

[15] Jacques M.A., Écologie quantitative et physiologie de la communauté bactérienne épiphylle de Cichorium endiva var. latifolia L., Thèse de doctorat, Université de Paris-Sud-Orsay, France, 1994, 111p.

[16] Jacques M.A., Morris C.A., Review of issues related to the quantification of bacteria from the phyllosphere, FEMS Microbiol. Ecol. 18 (1995) 1-14.

[17] Janse J.D., Derks J.H.J., Spit B.E., Van Der Tuin W.R., Classification of fluorescent soft rot Pseudomonas bacteria, including $P$. marginalis strains, using whole cell fatty acid analysis, Syst. Appl. Microbiol. 15 (1992) 538-553.

[18] Jessen O., Pseudomonas aeruginosa and other green fluorescent pseudomonads. A taxonomic study, Copenhagen: Munksgaard, 1965.

[19] Johnson J., Palleroni N.J., Desoxyribonucleic acid similarities among Pseudomonas species, Int. J. Syst. Bacteriol. 39 (1989) 230-235.

[20] Johnsen K., Nielsen P., Diversity of Pseudomonas strains isolated with King's B and Gould's S1 agar determined by repetitive extragenic palindromic-polymerase chain reaction, 16S rDNA sequencing and Fourier transform infrared spectrroscopy characterisation, FEMS Microb. Lett. 173 (1999) 155-162.

[21] Johnsen K., Andersen S., Jacobsen C.S., Phenotypic and genotypic characterization of phenanthrene-degrading fluorescent Pseudomonas biovars, Appl. Environ. Microbiol. 62 (1996) 3818-3825.

[22] Keel C., Weller D.M., Natsh A., Defago G., Cook R.J., Thomashow L.S., Conservation of the 2,4diacetylphloroglucinol biosynthesis locus among fluorescent Pseudomonas strains from diverse geographic locations, Appl. Environ. Microbiol. 62 (1996) 552-563.

[23] Kersters K., Ludwig W., Vancanneyt M., Devos P., Gillis M., Schleifer K.H., Recent changes in the classification of pseudomonads: an overview, Syst. Appl. Microbiol. 19 (1996) 465-477.

[24] Laguerre G., Rigottier-Gois L., Lemanceau P., Fluorescent Pseudomonas species categorized by using polymerase chain reaction (PCR)/restriction fragment analysis of 16S rDNA, Mol. Ecol. 3 (1994) 479-487.

[25] Latour X., Lemanceau P., Carbon and energy metabolism of oxidase-positive saprophytic fluorescent Pseudomonas spp., Agronomie 17 (1997) 427-443. 
[26] Latour X., Corberand T., Laguerre G. Lemanceau P., The composition of fluorescent pseudomonad populations associated with roots is influenced by plant and soil type, Appl. Environ. Microbiol. 62 (1996) 2449-2556.

[27] Latour X., Philippot L., Corberand T., Lemanceau P., The establishment of an introduced community of fluorescent pseudomonads in the soil and in the rhizosphere is affected by the soil type, FEMS Microbiol. Ecol. 30 (1999) 163-170.

[28] Lelliott R.A., Billing E., Hayward A.C., A determinative scheme for the fluorescent plant pathogenic Pseudomonas, J. Appl. Bacteriol. 29 (1966) 470-489.

[29] Lemanceau P., Beneficial effects of rhizobacteria on plants: example of fluorescent Pseudomonas spp., Agronomie 12 (1992) 413-437.

[30] Lemanceau P., Corberand T., Gardan L., Latour X., Laguerre G., Boeufgras J.M., Alabouvette C., Effect of two plant species, flax (Linum usitatissinum L.) and tomato (Lycopersicon esculentum Mill.) on the diversity of soilborne populations of fluorescent pseudomonads, Appl. Environ. Microbiol. 61 (1995) 1004-1012.

[31] Merieau A., Gügi B., Guespin-Michel J.F., Orange N., Temperature regulation of lipase secretion by Pseudomonas fluorescens strain MFO, Appl. Microbiol. Biotechnol. 39 (1993) 104-109.

[32] Meyer J.M., Stintzi A., De Vos D., Cornelis P., Tappe R., Taraz K., Budzikiewic H., Use of siderophores to type pseudomonads: the three Pseudomonas aeruginosa pyoverdine systems, Microbiology 143 (1997) 35-43.

[33] Molin M., Ternström A., Phenotypically based taxonomy of psychrotrophic Pseudomonas isolated from spoiled meat, water, and soil, Int. J. Syst. Bacteriol. 36 (1986) 257-274.

[34] Moore E.R.B., Mau M., Arnscheidt A., Böttger E.C., Hutson R.A., Collins M.D., Van de Peer Y., De Wachter R., Timmis K.N., The determination and comparison of the 16S rRNA gene sequences of species of the genus Pseudomonas (sensu stricto) and estimation of the natural intrageneric relationships, Syst. Appl. Microbiol. 19 (1996) 478-492.

[35] Palleroni N.J., Gram-negative aerobic rods and cocci: Family I Pseudomonadaceae, in: Krieg N.R., Holt J.G. (Eds.), Bergey's manual of bacteriology, William and Wilkins, Baltimore, 1984, pp. 141-168.

[36] Palleroni N.J., Human- and Animal-Pathogenic, in: Ballows A., Trüper H.G., Dworkin M., Harder W., Schleifer KH (Eds.), The Prokaryotes, Springer Verlag, New-York, 1992, pp. 3086-3103.
[37] Palleroni N.J., Introduction to the family Pseudomonadaceae, in: Ballows A., Trüper H.G., Dworkin M., Harder W., Schleifer K.H. (Eds.), The Prokaryotes, Springer Verlag, New-York, 1992, pp. 3071-3085.

[38] Palleroni N.J., Ballard R.W., Ralston E., Doudoroff M., Desoxyribonucleic acid homologies among some Pseudomonas species, J. Bacteriol. 110 (1972) 1-11.

[39] Palleroni N.J., Kunisawa R., Contopolou R., Doudoroff M., Nucleic acid homologies in the genus Pseudomonas, Int. J. Syst. Bacteriol. 23 (1973) 333-339.

[40] Raaijmakers J.M., Weller D.M., Natural plant protection by 2,4-diacetylphloroglucinol-producing Pseudomonas spp. in take-all decline soils, M P M I 11 (1998) 144-152.

[41] Rainey P.B., Bailey M.J., Thompson I.P., Phenotypic and diversity of fluorescent pseudomonads isolated from field-grown sugar beet, Microbiology 140 (1994) 2315-2331.

[42] Schleifer K.H., Amann R., Ludwig W., Rothemund C., Springer N., Dorn S., Nucleic acid probes for the identification and in situ detection of pseudomonads, in: Galli E., Silver S., Witholt B. (Eds.), Pseudomonas molecular biology and biotechnology, Am. Soc. Microbiol., Washington, DC, 1992, 127-134.

[43] Sneath P.H.A., Basic program for a significance test for two clusters in Euclidian spas as meas used by their over lab, Computers Geosci. 5 (1979) 143-155.

[44] Sneath P.H.A., Sokal R.R., Numerical taxonomy, in: Kennedy D., Park R.B., (Eds.), The principles of numerical classification, Freemann W H, San Fransisco, 1973, 573p.

[45] Sneath P.H.A., Stevens M., Sackin M., Numerical taxonomy of Pseudomonas based on published records of substrate utilization, Antonie Van Leeuwenhoek 47 (1981) 423-448.

[46] Sorensen J., Skouv J., Nybroe O., Rapid identification of environmental isolates of Pseudomonas aeruginosa, $P$. fluorescens and $P$. putida by SDS PAGE analysis of whole-cell protein patterns, FEMS Microbiol. Ecol. 101 (1991) 41-50.

[47] Stackebrandt E., Goebel B.M., Taxonomic note: a place for DNA-DNA reassociation and rRNA sequence analysis in the present species definition in bacteriology, Int. J. Syst. Bacteriol. 44 (1994) 846-849.

[48] Stanier R.Y., Palleroni N.J., Doudoroff M., The aerobic pseudomonads, a taxonomy study, J. Gen. Microbiol. 43 (1966) 159-271. 
[49] Stead D.E., Grouping of plant-pathogenic and some other Pseudomonas spp. by using cellular fatty acid profiles, Int. J. Syst. Bacteriol. 42 (1992) 281-295.

[50] Stenström I.M., Zakaria A., Terström A., Molin G., Numerical taxonomy of fluorescent Pseudomonas associated with tomato roots, Antonie Van Leeuwenhock 57 (1990) 223-236.

[51] Vancanneyt M., Torck U., Dewettinck D., Vaerewijck M., Kersters K., Grouping of pseudomonads by SDS-PAGE of whole-cell proteins, Syst. Appl. Microbiol. 19 (1996) 556-568.

[52] Van Overbeek L.S., Van Elsas J.D., Root exudate-induced promoter activity in Pseudomonas fluorescens mutants in the wheat rhizosphere, Appl. Environ. Microbiol. 61 (1995) 890-898.

[53] Wayne L.G., Brenner D.J., Colwell R.R., Grimont P.A.D., Kandler O., Krichevsky M.I., Moore L.H., Moore W.E.C., Murray R.G.E., Stackebrandt E.,
Staar M.P., Trüper H.G., Report of the ad hoc committee on reconciliation of approaches to bacterial systematic, Int. J. Syst. Bacteriol. 37 (1987) 463-464.

[54] Weller D.M., Biological control of soilborne plant pathogens in the rhizosphere with Bacteria, Annu. Rev. Phytopathol. 26 (1988) 379-407.

[55] Widmer F., Seidler R.J., Gillevet P.M., Watrud L.S., Di Giovanni G.D., A highly selective PCR protocol for detecting 16S rRNA genes of the genus Pseudomonas (sensu stricto) in environmental samples, Appl. Environ. Microbiol. 64 (1998) 2545-2553.

[56] Woese C.R., Bacterial evolution, Microbiol. Rev. 51 (1987) 221-271.

[57] Young J.M., Takikawa Y., Gardan L., Stead D.E., Changing concepts in the taxonomy of plant pathogenic bacteria, Annu. Rev. Phytopathol. 30 (1992) 67-105. 